Canadian

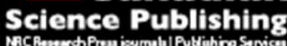

Applied Physiology, Nutrition, and Metabolism Physiologie appliquée, nutrition et métabolisme

\title{
Metabolic state can define the ovarian response to environmental contaminants and medicinal plants
}

\begin{tabular}{|r|l|}
\hline Journal: & Applied Physiology, Nutrition, and Metabolism \\
\hline Manuscript ID & apnm-2017-0262.R1 \\
\hline Manuscript Type: & Article \\
\hline Date Submitted by the Author: & $09-J u n-2017$ \\
\hline Complete List of Authors: & $\begin{array}{l}\text { Sirotkin, Alexander; Constantine the Philosopher University } \\
\text { Fabian, Dušan ; Slovak Academy of Sciences } \\
\text { Babel'ová (Kubandová), Janka ; Slovak Academy of Sciences } \\
\text { Vlčková, Radoslava ; University of Veterinary Medicine and Pharmacy } \\
\text { Alwasel, Saleh; King Saud University } \\
\text { Harrath, Abdel Halim; King Saud University; Universite de Tunis El Manar }\end{array}$ \\
\hline $\begin{array}{r}\text { Is the invited manuscript for } \\
\text { consideration in a Special } \\
\text { Issue? : }\end{array}$ & $\begin{array}{l}\text { Keyword: } \\
\text { testosterone, IGF-I }\end{array}$ \\
\hline \multicolumn{2}{|c|}{}
\end{tabular}


Metabolic state can define the ovarian response to environmental contaminants and medicinal plants

Alexander V. Sirotkin ${ }^{1,2}$, Dušan Fabian ${ }^{3}$, Janka Babel'ová (Kubandová) ${ }^{3}$, Radoslava Vlčková4 Saleh Alwasel $^{5}$, Abdel Halim Harrath ${ }^{5}$

${ }^{1}$ Dept. Zoology and Anthropology, Constantine the Philosopher University, 94974 Nitra, Slovakia

${ }^{2}$ Dept. Genetics and Reproduction, Research Institute of Animal Production, 94959 Lužianky, Slovakia

${ }^{3}$ Institute of Animal Physiology, Slovak Academy of Sciences, 04001 Košice, Slovakia

${ }^{4}$ Department of Anatomy, Histology, and Physiology, Institute of Physiology, University of Veterinary Medicine and Pharmacy, 04181 Košice, Slovakia

${ }^{5}$ Department of Zoology, College of Science, King Saud University, Riyadh, Saudi Arabia

\section{Corresponding author:}

Prof. Dr. Abdel Halim Harrath

Dept. Zoology, King Saud University, 11451 Riyadh, Saudi Arabia. Tel: +966535862799, Email: hharrath@ksu.edu.sa

Short title: Metabolic status-dependent ovarian response 


\begin{abstract}
Environmental contaminants and medicinal plants can affect reproductive processes. The aim of this study was to investigate the effect of maternal metabolic status on the response of mouse ovaries to the environmental contaminants benzene and xylene, as well as to extracts of the medicinal yucca plant. Ovaries isolated from normal-lean and slightly obese mice were cultured with or without $0.1 \%$ benzene or xylene for $24 \mathrm{~h}$. Similarly, ovaries isolated from normal-lean, slightly obese, and significantly obese mice were cultured for $24 \mathrm{~h}$ with or without an extract of Yucca shildegera (YS, $10 \mu \mathrm{g} / \mathrm{mL}$ ). We found that the metabolic status did not influence basal P4, T or IGF-I release, but obesity influenced the effects of environmental contaminants and YS. Benzene reduced P4 output only in ovaries from obese, but not normal-lean, mice; it also reduced IGF-I (but not T) release from ovaries irrespective of their metabolic status. Xylene dramatically increased P4 and T (but not IGF-I) release by ovaries from normal-lean mice, but there were no changes in P4 and only small increases in $\mathrm{T}$ output in obese mice. YS increased P4 (but not T or IGF-I) release in lean and slightly obese animal ovaries, whilst significant obesity was associated with a lack of P4 response to YS.

Obesity might affect the basal ovarian release of $\mathrm{T}$ or IGF-I and increases the sensitivity of ovaries to the action of benzene, but decreases their responsiveness to xylene and YS.
\end{abstract}

Key words: ovary, obesity, benzene, xylene, Yucca shildegera, progesterone, testosterone, IGF-I 


\section{Introduction}

Environmental pollution, the obesity epidemic, and development of alternative medicines based on natural products have increased the incidence of reproductive problems, prompting a corresponding increase in research aimed at understanding how these phenomena impact reproduction. Although the influence of metabolic state/obesity (Hernandez-Medrano et al. 2012; Dupont et al. 2014; Walzem and Chen 2014; Broughton and Moley 2017), certain medicinal plants (Sirotkin and Harrath 2014; Daniyal and Akram 2015; Sabourian et al. 2016; Yazbek et al. 2016), and oil-related environmental contaminants (Protano et al. 2012; Webb et al. 2014; Sirotkin and Harrath 2017) on early reproduction have been reported, the interrelationship between these factors requires further understanding. The influence of environmental contaminants or medicinal plants on reproduction can theoretically depend on metabolic status. Therefore, their effects can be either improved or corrected by changes in caloric intake. There are publications describing the influence of environmental contaminants and medical plants on metabolism (see above), but not vice versa. In the current literature, we failed to find any information on how metabolic status affects the response of the reproductive system to environmental contaminants or medicinal plants.

The aim of this study was to investigate the effect of body fat content on the response of mouse ovaries to the oil-related environmental contaminants benzene and xylene, as well as the medicinal plant yucca. We elected to examine the effects of benzene and xylene because their adverse effects on both human and animal female reproductive functions has been well documented (Protano et al. 2012; Webb et al. 2014; Sirotkin and Harrath 2017). Among medicinal plants, we selected the plant Yucca shildegera (YS), which has recently been shown to have a potent effect on ovarian function (Khalifa et al. 2014; Štochmal'ová et al. 2015; Vlčková et al. 2017). 
We compared the influence of these treatments on the release of steroids (progesterone P4, and testosterone T) and a peptide hormone (insulin-like growth factor I, IGF-I) released by cultured ovaries isolated from mice with different levels of adiposity. It has been previously demonstrated that the release of these hormones can be influenced by xylene, benzene (Webb et al. 2014; Sirotkin and Harrath 2017), and YS (Štochmal'ová et al. 2015; Vlčková et al. 2017). These hormones are considered important mediators of reproduction, and key regulators of ovarian function and fecundity, as well as markers of ovarian activity (Hernandez-Medrano et al. 2012; Sirotkin 2014).

\section{Materials and Methods}

Animals and experimental design

All animal experiments were reviewed and approved by the Ethical Committee for Animal Experimentation at the Institute of Animal Physiology, and approved by the State Veterinary and Food Administration of the Slovak Republic (Ro 2399/15-221). The studies were performed in accordance with the related Slovakian regulations and EC Directive 86/609/EEC on the protection of animals used for experimental and other scientific purposes.

For these studies, we used the previously validated two-generation model (Kubandová et al. 2014a; Kubandová et al. 2014b; Fabian et al. 2015; Janštová et al. 2017) that resulted in the production of offspring, which manifested the signs of obesity at the time of sexual adulthood. All experiments were performed on mice dams of the outbred ICR strain (Velaz, Prague, Czech Republic). Adult female mice (35 days old) of the parental generation were subjected to hormonal synchronization and stimulation with pregnant mare's serum gonadotropin (eCG 5 IU ip; Folligon, Intervet International, Boxmeer, Holland), followed 47 h later by administration of human chorionic gonadotropin (hCG 4 IU ip; Pregnyl, Organon, Oss, Holland)] and mated with males of the same strain overnight. Mated dams were 
randomly divided into two groups: control and experimental. During both gestation (21 days) and the lactation period (from birth to weaning: 21 days), dams in the control group were fed a standard pellet diet (M1, Ricmanice, Czech Republic; $3.2 \mathrm{kcal} / \mathrm{g}$ ) ad libitum. Dams in the experimental group were fed a standard M1 diet with the addition of the high-energy product Ensure Plus (liquid diet containing $1.5 \mathrm{kcal} / \mathrm{ml}$ ). Mice females of F1 generation were used as donors of ovaries. To minimize the impact of actual nutrition on the ovarian cycle, after weaning, all F1 mice delivered from both control and experimental dams were only fed a standard pellet diet. At day 35 of age, F1 females were weighed individually, scanned with an EchoMRI (Whole Body Composition Analyser, Echo Medical System, Houston, Texas, USA) for the evaluation of body fat deposits, and allocated into three groups based on their percentage of body fat: Females delivered from control dams were assigned as (1) normallean controls with low to normal amounts of body fat $(<8 \%)$; and females delivered from experimental dams were classified as: (2) slightly obese animals with slightly elevated body fat $(8-11 \%$, ) and (3) obese animals with highly elevated body fat (>11\%).

\section{Ovarian culture}

Ovaries were dissected from all F1 females following euthanization, carefully separated from adipose and other surrounding tissues, washed several times in $95 \%$ alcohol, sterile physiological solution $(0.9 \% \mathrm{NaCl})$, and then incubated (two ovaries/well) in 24-well cell culture plates (Becton Dickinson, Lincoln Park, New Jersey, USA) containing $1 \mathrm{~mL}$ of sterile DMEM/F12 (1:1 ratio) culture medium (BioWhittaker ${ }^{\mathrm{TM}}$, Verviers, Belgium) supplemented with $10 \%$ fetal bovine serum $\left(\right.$ BioWhittaker $^{\mathrm{TM}}$ ) and $1 \%$ antibiotic/antimycotics (Sigma, St. Louis, MO, USA). In the first series of experiments, ovaries isolated from control (normal-lean) and slightly obese animals were cultured with or without $0.1 \%$ benzene or xylene (Sigma). In the second series of experiments, ovaries isolated from control (normal- 
lean), slightly obese, and significantly obese mice were cultured with or without a Yucca shildegera extract (10 $\mu \mathrm{g} / \mathrm{mL}$, "Mexican Yucca Powder", Konfirm Company, Brno, Czech Republic).

Control cultures were formed by ovaries cultured without any additions or by incubation with medium cultured without ovaries and treatments (assay blank). After $1 \mathrm{~d}$ of culture, the culture medium was removed from the wells, using a syringe, and stored at $-70^{\circ} \mathrm{C}$ until used for radioimmunoassay (RIA).

\section{Immunoassay}

The concentrations of P4, T, and IGF-I were determined in duplicate in the culture media, using the appropriate RIA kit according to the manufacturer's instructions (P4 and TIzotop, Budapest, Hungary, IGF-I- DRG Instruments GmbH, Marburg, Germany). The RIA for IGF-I included an IGF-I extraction procedure. The antiserum against P4 had crossreactivities of less than $13 \%$ to 17 -hydroxyprogesterone, $0.03 \%$ to pregnenolone, $0.07 \%$ to cortisol, $0.6 \%$ to corticosterone, $0.08 \%$ to 11 -dezoxi-17-hydroxycorticosterone, $0.01 \%$ to testosterone, $0.003 \%$ to estriol, and $0.001 \%$ to 5-dihydrotestosterone, 17-estradiol, dehydroepiandrosterone. The sensitivity of the P4 assay was $0.44 \pm 0.12 \mathrm{nmol} / \mathrm{L}$, and the intra- and inter-assay coefficients of variation did not exceed $10.2 \%$ and $11.8 \%$, respectively. The sensitivity of the $\mathbf{T}$ assay was $0.087 \mathrm{nmol} / \mathrm{L}$. The intra- and inter-assay coefficients of variation did not exceed $6.72 \%$ and $9.63 \%$, respectively. The cross-reactivity of the antiserum against $\mathrm{T}$ was less than $35 \%$ to $5 \alpha$-dihydrotestosterone, $0.8 \%$ to $5 \beta$-dihydrotestosterone, and $0.01 \%$ to $17 \beta$-estradiol and cortisol. The cross-reactivity of the antiserum against IGF-I was non-detectable (less than $0.0001 \%$ ) to IGF-II, insulin, proinsulin, and growth hormone. The maximal intra- and inter-assay coefficients of variation were $3.4 \%$ and $8.2 \%$, respectively. 
The sensitivity of the assay was $0.8 \mathrm{ng} / \mathrm{mL}$. All RIAs were validated for use in samples of culture medium by dilution tests.

\section{Statistics}

Each experiment was performed twice with 20-60 animals per group. Each experimental group was represented by 4-15 culture wells (two ovaries per well). Differences between groups were evaluated by a two-way ANOVA test followed by a Fisher's LSD test, using the statistics software Sigma Plot 11.0 (Systat Software, GmbH, Erkhart, Germany). Values represent the mean \pm SEM. Differences were compared for statistical significance at P-levels less than $0.05(\mathrm{P}<0.05)$.

\section{Results}

The isolated, cultured, mouse ovaries produced substantial amounts of P4, T, and IGF-I; the amount of hormones released was affected by the presence of environmental contaminants and the YS extract.

Metabolic status, as assessed by degree of mouse adiposity, did not substantially affect the basal release of P4 (Fig. 1a and 2a ) T (Fig. 1b and 2b) or IGF-1 (Fig. 1c and 2c).

In the first series of experiments examining the effect of environmental contaminants, benzene reduced $\mathrm{P} 4$ secretion only in ovaries from slightly obese mice, but not in ovaries from normal-lean mice (Fig. 1a). Benzene reduced IGF-I secretion (Fig. 1c), but not T secretion (Fig.1b) in ovaries from all animals irrespective of their metabolic status. In contrast, xylene dramatically increased both P4 (Fig. 1a) and T (Fig. 1b) secretion, but not IGF-I secretion (Fig. 1c) from the ovaries of lean normal mice, whereas in contrast, in the 
ovaries of slightly obese mice, xylene did not affect either P4 (Fig. 1a) or IGF-I (Fig. 1c) secretion and only a small increase in T secretion (Fig. 1b) occurred.

In the second series of experiments, examining the effect of the YS extract, the addition of the YS extract increased P4 secretion in ovaries isolated from normal-lean mice as well as those isolated from slightly-obese animals, with no effect being observed on animals with significant obesity (Fig. 2a). The YS extract had no effect on ovarian T secretion (Fig. 2b) and IGF-I secretion (Fig. 2c), regardless of metabolic status.

\section{Discussion}

Does metabolic state control mice fecundity via ovarian P4, T, or IGF-I?

Previous studies in this model (Kubandová et al. 2014a; Kubandová et al. 2014b; Fabian et al. 2015; Janštová et al. 2017; Chi et al. 2000; Jungheim et al. 2010; Herrid et al. 2014; PérezPérez et al. 2015) demonstrated a significant influence of metabolic status on fertility and embryo quality. In our experiments, metabolic status did not substantially influence the basal release of P4, T or IGF-I, release. The involvement of these hormones in the control of mammalian (including mice) ovarian follicullogenesis, oogenesis, and fertility has been demonstrated in numerous previous studies (Hernandez-Medrano et al. 2012, Sirotkin 2014). Therefore, it might be hypothesized that metabolic status does not affect mouse reproduction through changes in basal ovarian steroid or IGF-I release, although metabolism-dependent changes in the upstream regulators of these hormones, the ovarian response to these upstream regulators, or to P4, T, or IGF-I ought not to be excluded. The latter hypothesis is confirmed by the fact that obesity in mice is associated with both impaired fertility and alterations in IGF-I receptors in the reproductive system (Chi et al. 2000; Jungheim et al. 2010). Taken together, our observations suggest that the effect of metabolic status on mice fecundity is not mediated by basal release of ovarian T or IGF-I. 
Do environmental contaminants benzene and xylene directly affect ovarian functions?

Several previous studies have demonstrated the adverse influence of the environmental contaminants studied here on human and animal reproduction and fertility at various levels, including on ovarian hormones (Sirotkin and Harrath 2017). The negative correlation between ovarian follicular fluid benzene levels and the levels of plasma steroid hormones in women (Alviggi et al. 2014) suggests that this contaminant can downregulate ovarian steroidogenesis, although it is not known whether benzene has a direct or indirect effect on steroidogenesis. Xylene has previously been shown to reduce P4 and estradiol levels in rat plasma, but did not affect the release of these hormones by rat ovaries (Ungváry et al. 1981). Benzene and related oil-related contaminants are able to alter the release of GnRH and gonadotropins from the hypothalamus (Alviggi et al. 2014; Stepanov et al. 1990). These reports suggest that environmental contaminants can affect ovarian hormones probably by modulating upstream regulators of ovarian function. Our observations of the effects of benzene and xylene on P4, $\mathrm{T}$, and IGF-I release in isolated ovaries represent the first demonstration of the direct action of environmental contaminants on ovarian steroid and peptide hormone secretion. Since these hormones are considered key regulators in reproduction and fertility (Hernandez-Medrano et al. 2012, Sirotkin. 2014), it is highly probable that environmental contaminants can disrupt reproductive processes via a direct action on the release of ovarian steroid and peptide hormones.

Does metabolic state affect the response of ovarian hormones to environmental contaminants?

The environmental contaminants in our experiment dramatically changed ovarian hormone release, but these changes were highly dependent on the metabolic status of the host animal. For example, benzene reduced ovarian hormone output only in slightly obese mice. Xylene 
promoted hormone release but only predominantly in normal mice, whereas the ovaries of slightly obese mice were not affected by xylene. These observations suggest that metabolic status can define the ovarian response to external factors: obesity increases the response of ovaries to the action of benzene and simultaneously decreases the response of ovaries to xylene action. The mechanism of these obesity-dependent differences in response of ovarian cells to different environmental contaminants remains to be elucidated. Fat per se is probably not the main cause of these differences because in our experiments the fat was carefully removed from the ovaries before culture. More probable is the influence of body fat on ovaries before their isolation, either via a non-specific effect on metabolism and resistance of cells to environmental toxins, or through the action of fat-derived adipokines whose influence on ovarian functions in mammals including mice is well documented (Kubandová et al. 2014a; Kubandová et al. 2014b; Janštová et al. 2017, Sirotkin. 2011; Allen et al. 2016; Cheng et al. 2016). From a practical viewpoint, the variability in metabolic status/fat content can explain the individual variability of human and animals in their resistance to environmental contaminants. Moreover, it cannot be excluded that this resistance could be improved by changes in metabolic status, for example by adequate feeding (intake of calories or functional food).

\section{Does yucca directly affect ovarian functions?}

The influence of functional foods containing particular medicinal plant extracts on ovarian functions have been well described (Sirotkin and Harrath 2014; Daniyal and Akram 2015; Sabourian et al. 2016; Yazbek et al. 2016). One of the most potent regulators is YS. In

previous experiments, YS reduced ovine ovarian follicullogenesis, steroidogenesis, and responsiveness to FSH (Vlčková et al. 2017), and promoted ovarian P4 release in rabbits (Štochmal'ová et al. 2015), as well as increased the conception and kindling rate in goats 
(Khalifa et al. 2014) and rabbits (Štochmal'ová et al. 2015). The present experiments provide the first demonstration of the stimulatory influence of YS on mice ovaries as well. The YSinduced upregulation of $\mathrm{P} 4$ release by isolated ovaries demonstrates the direct action of this plant extract on mouse ovarian steroidogenesis. These observations are in line with our previous reports of a direct action of YS on steroidogenesis in isolated rabbit (Štochmal'ová et al. 2015) and sheep (Vlčková et al. 2017) ovaries. YS has also been reported to stimulate goat and rabbit fecundity (Khalifa et al. 2014; Štochmal'ová et al. 2015). Therefore, the potential application of YS as a biostimulator of reproduction in other species, including mouse and humans, cannot be excluded. Since P4 is considered a key regulator of female reproduction [Sirotkin 2014], it is possible that YS can affect reproduction via changes in ovarian steroidogenesis.

Does metabolic state affect the response of ovarian hormones to yucca?

The beneficial YS action on animal nutrition and metabolism (Ikedo et al. 1996; Singer et al. 2008) has been reported, but the reverse action, i.e., the effect of metabolic status on YS effects has not yet been reported. Our observations represent the first demonstration that metabolic status can define YS action. Here, we showed that the YS extract promoted ovarian P4 release only in normal-lean and slightly obese mice, but the ovaries of highly obese mice did not respond to YS addition. The reasons behind these different responses remain unknown, but their biological significance might be hypothesized. In metabolically normal animals, YS can improve metabolism and cell nutrition, but under condition of high obesity, cell over-nutrition would be prevented by a feedback mechanism inhibiting YS`s effect. It might be that ovarian hormones can mediate the effect of both metabolism and YS on reproduction. YS and obesity have opposite effects on ovarian function, but similar sites of action, namely on ovarian cell apoptosis and hormone release (Hernandez-Medrano et al. 
2012; Broughton and Moley 2017, Štochmal'ová et al. 2015; Vlčková et al. 2017; Kubandová et al. 2014a; Kubandová et al. 2014b; Janštová et al. 2017). Therefore, a functional interrelationship between YS and obesity in the control of these processes might be expected. One such common site of action could be P4 whose release from the ovary was affected by YS in both the present (mice) and past (rabbit: (Štochmal'ová et al. 2015), sheep: (Vlčková et al. 2017) studies. The involvement of the other potential mediator of YS on murine ovary function, IGF-I, is less probable. Although IGF-I can influence nutrition, metabolism and rat, porcine, bovine, and human ovarian functions (Hernandez-Medrano et al. 2012; Broughton and Moley 2017) and its release was affected by YA in sheep (Vlčková et al. 2017), YS did not affect murine ovarian IGF-I release in the present experiments. Independent of the interrelationships between metabolism, YS, and reproduction, our present observations could be useful from a practical viewpoint. It might be expected that YS would not promote reproduction and fecundity in obese animals whose ovaries were insensitive to YS action, i.e., obesity has an adverse effect on both natural and YS-promoted reproduction.

The mechanisms of action and functional interrelationship between particular environmental factors (contaminants and medicinal plants) and metabolism and reproduction, as well as the practical aspects of such interrelationships are worthy of further study. Nevertheless, the present observation represent the first demonstration that (1) the effect of metabolic status on mouse reproduction is not mediated by the basal ovarian release of P4, T or IGF-I, (2) the environmental contaminants benzene and xylene and the medicinal plant yucca can directly affect the release of ovarian hormones in mice, and (3) metabolic status can define the ovarian response to environmental contaminants and medicinal plants; obesity increases the sensitivity of mouse ovaries to the action of benzene but decreases their responsiveness to xylene and YS. 


\section{Conflict of interest}

The authors report no conflicts of interest associated with this manuscript.

\section{Acknowledgements}

The authors thank Ing. Ladislav Tyl (Konfirm, Brno, Czech Republic) for providing Yucca schidigera extract, Dr. Tatiana Červenková, Ing. Žofia Kuklová and Ms. Katarina Tothová (Research Institute of Animal Production, Lužianky, Slovakia) for assistance during experiments, hormone assays and statistical analysis. This work was supported by the Slovak Research and Development Agency under the contracts no. APVV-4040-11, APVV-15-0296, APVV-14-0763 and VEGA 1/0392/17. The authors would like to extend their sincere appreciation to the Deanship of Scientific Research at King Saud University for funding this Research group RGP-164.

\section{References}

Allen, S.J., Garcia-Galiano, D., Borges, B.C., Burger, L.L., Boehm, U., and Elias, C.F. 2016. Leptin receptor null mice with re-expression of LepR in GnRHR expressing cells display elevated FSH levels but remain in a prepubertal state. Am. J. Physiol. Regul. Integr. Comp. Physiol. 310:R1258-R1266. doi: 10.1152/ajpregu.00529.2015. PMID: 27101301.

Alviggi, C., Guadagni, R., Conforti, A., Coppola, G., Picarelli, S., De Rosa, P., et al. 2014. Association between intrafollicular concentration of benzene and outcome of controlled ovarian stimulation in IVF/ICSI cycles: a pilot study. J. Ovarian. Res. 7:67. doi: 10.1186/1757-2215-7-67. PMID: 24991235.

Broughton, D.E., and Moley, K.H. 2017. Obesity and female infertility: potential mediators of obesity's impact. Fertil. Steril. DOI:10.1016/j.fertnstert. 01.017. PMID: 28292619. 
Catteau, A., Caillon, H., Barrière, P., Denis, M.G., Masson, D., and Fréour, T. 2016. Leptin and its potential interest in assisted reproduction cycles. Hum. Reprod. Update. DOI: 10.1093/humupd/dmv057. PMID: 26663219.

Cheeke, P.R. 1996. Biological effects of feed and forage saponins and their impact on animal production, pp. 377-386. In: Waller G. \& Yamasaki Y. (eds), Saponins used in food and agriculture. Plenum Press, New York.

Cheng, L., Shi, H., Jin, Y., Li, X., Pan, J., Lai, Y., et al. 2016. Adiponectin deficiency leads to female subfertility and ovarian dysfunctions in mice. Endocrinology, 157:4875-4887. DOI: 10.1210/en.2015-2080. PMID: 27700136.

Chi, M.M., Schlein, A.L., and Moley, K.H. 2000. High insulin-like growth factor 1 (IGF-1) and insulin concentrations trigger apoptosis in the mouse blastocyst via down-regulation of the IGF-1 receptor. Endocrinology, 141:4784-4792. DOI: 10.1210/endo.141.12.7816. PMID: 11108294.

Daniyal, M., and Akram, M. 2015. Antifertility activity of medicinal plants. J. Chin. Med. Assoc. 78:382-388. DOI: 10.1016/j.jcma.2015.03.008. PMID: 25921562.

Dupont, J., Scaramuzzi, R.J., and Reverchon, M. 2014. The effect of nutrition and metabolic status on the development of follicles, oocytes and embryos in ruminants. Animals, 8:10311044. DOI:10.1017/S1751731114000937. PMID: 24774511.

Fabian, D., Kubandová, J., Čikoš, Š., Burkuš, J., Fabianová, K., Račeková, E., et al. 2015. The effect of maternal body condition on in vivo production of zygotes and behavior of delivered offspring in mice. Theriogenology, 83:577-589. DOI: 10.1016/j.theriogenology.2014.10.025. PMID: 25433834.

Hernandez-Medrano, J.H., Campbell, B.K., and Webb, R. 2012. Nutritional influences on folliculogenesis. Reprod. Domest. Anim. 4:274-282. DOI: 10.1111/j.14390531.2012.02086.x. PMID: 22827381. 
Herrid, M., Palanisamy, S.K., Ciller, U.A., Fan, R., Moens, P., Smart, N.A., et al. 2014. An updated view of leptin on implantation and pregnancy: a review. Physiol. Res. 63:543-557. PMID: 24908087.

Ikedo, S., Shimoyamada, M., and Watanabe, K. 1996. Interaction between bovine serum albumin and saponin as studied by heat stability and protease digestion. J. Agric. Food. Chem. 44:792-795. DOI: $10.1021 /$ jf940742.

Janštová, Ž., Burkuš, J., Kubandová, J., Fabian, D., Koppel, J., and Čikoš, Š. 2017. The effect of maternal stress on blastocyst quality depends on maternal physiological status. Gen. Physiol. Biophys. 36:53-63. DOI: 10.4149/gpb_2016019. PMID: 27447403.

Jungheim, E.S., Schoeller, E.L., Marquard, K.L., Louden, E.D., Schaffer, J.E., and Moley, K.H. 2010. Diet-induced obesity model: Abnormal oocytes and persistent growth abnormalities in the offspring. Endocrinology, 151:4039-4046. DOI: 10.1210/en.2010-0098. PMID: 20573727.

Khalifa, E.I., Hanan, A.M.H., Mohamed, A.H., and Hussein, A.M. 2014. Effects of using Yucca schidigera powder as feed additive on productive and reproductive efficiency of Zairaby dairy goats. Egyptian J. Sheep Goat Sci. 9:9-21.

Kubandová, J., Cikoš, S., Burkuš, J., Czikková, S., Koppel, J., and Fabian, D. 2014a. Amount of maternal body fat significantly affected the quality of isolated mouse preimplantation embryos and slowed down their development. Theriogenology, 81:187-195. DOI: 10.1016/j.theriogenology.2013.10.014. PMID: 24238400.

Kubandová, J., Fabian, D., Burkuš, J., Cikoš, Š., Czikková, S., Mozeš, Š., et al. 2014b. Twogeneration diet-induced obesity model producing mice with increased amount of body fat in early adulthood. Physiol. Res. 63:103-113. PMID: 24182339. 
Pérez-Pérez, A., Sánchez-Jiménez, F., Maymó, J., Dueñas, J.L., Varone, C., and SánchezMargalet, V. 2015. Role of leptin in female reproduction. Clin. Chem. Lab. Med. 53:15-28. DOI: 10.1515/cclm-2014-0387. PMID: 25014521.

Protano, C., Scalise, T., Orsi, G.B., and Vitali, M. 2012. A systematic review of benzene exposure during pregnancy and adverse outcomes on intrauterine development and birth: still far from scientific evidence. Ann. Ig. 24:451-463. PMID: 23234183.

Sabourian, R., Karimpour-Razkenari, E., Saeedi, M., Bagheri, M.S., Khanavi, M., Sadati, N., et al. 2016. Medicinal plants used in Iranian traditional medicine (ITM) as contraceptive agents. Curr. Pharm. Biotechnol. 17:974-85. PMID: 27640645.

Singer, M.D., Robinson, P.H., Salem, A.Z.M., and Depeters, E.J. 2008. Impacts of rumen fluid modified by feeding Yucca schidigera to lactating dairy cows on in vitro gas production of 11 common dairy feedstuffs, as well as animal performance. Anim. Feed Sci. Tech. 146:242-258. doi.org/10.1016/j.anifeedsci.2007.12.010.

Sirotkin, A.V. 2011. The role and application of leptin in control of female reproductive functions. In: Leptin: Hormonal Functions, Dysfunctions and Clinical Use (eds. M. Hemling and A.T. Belkin), Nova Science Publishers, New York, USA, pp. 123-140.

Sirotkin, A.V. 2014. Regulators of Ovarian Functions - 2nd ed. - New York: Nova Science Publishers, Inc. 194 pp.

Sirotkin, A.V., and Harrath, A.H. 2014. Phytoestrogens and their effects. Eur. J.. Pharmacol. 741:230-236. DOI: 10.1016/j.ejphar.2014.07.057. PMID: 25160742.

Sirotkin, A.V., and Harrath, A.H. 2017. Influence of oil-related environmental pollutants on female reproduction. Reprod. Toxicol. 71:142-145. DOI: 10.1016/j.reprotox.2017.05.007. PMID: 28576684.

Stepanov, M.G., Altukhov, V.V., Proĭmina, F.I., Savchenko, O.N., and Danilova, O.A. 1990. Physiologic mechanisms of the reaction of the reproductive system in female rats to chronic 
exposure to low doses of toluene [in Russian] Fiziol Zh SSSR Im I M Sechenova. 76:10961102. PMID: 2177007.

Štochmal'ová, A., Földešiová, M., Baláži, A., Kádasi, A., Grossmann, R., Alexa, R., et al. 2015. Yucca schidigera extract can promote rabbit fecundity and ovarian progesterone release. Theriogenology, 30:1-5. DOI: 10.1016/j.theriogenology.2015.04.024. PMID: 26007608.

Ungváry, G., Varga, B., Horváth, E., Tátrai, E., and Folly, G. 1981. Study on the role of maternal sex steroid production and metabolism in the embryotoxicity of para-xylene. Toxicology, 19:263-268. PMID: 7233451.

Vlčková, R., Sopková, D., Andrejčáková, Z., Valocký, I., Kádasi, A., Harrath, A.H., et al. 2017. Dietary supplementation of yucca (Yucca schidigera) affects ovine ovarian functions. Theriogenology, 88:158-165. DOI: 10.1016/j.theriogenology.2016.09.026. PMID: 27746005. Walzem, R.L., and Chen, S.E. 2014. Obesity-induced dysfunctions in female reproduction: lessons from birds and mammals. Adv. Nutr. 5:199-206. DOI: 10.3945/an.113.004747. PMID: 24618762.

Webb, E., Bushkin-Bedient, S., Cheng. A., Kassotis, C.D., Balise, V., and Nagel, S.C. 2014. Developmental and reproductive effects of chemicals associated with unconventional oil and natural gas operations. Rev. Environ. Health. 29:307-318. DOI: 10.1515/reveh-2014-0057. PMID: 25478730.

Yazbek, P.B., Tezoto, J., Cassas, F., and Rodrigues, E. 2016. Plants used during maternity, menstrual cycle and other women's health conditions among Brazilian cultures. J. Ethnopharmacol. 179:310-331. DOI:10.1016/j.jep.2015.12.054. PMID: 26732633. 


\section{Figure legends}

Fig. 1a-c: Effect of environmental contaminants benzene and xylene $(0.1 \%)$ on ovarian progesterone (a), testosterone (b) and insulin-like growth factor I (IGF-I) (c) release in mice in different metabolic states.

Normal-lean mice: mice with low-to-normal amounts of body fat (defined as body fat content $<8 \%$ ) derived from dams fed with a standard diet. Slightly obese mice: mice with a slightly elevated body fat (8-11\%) derived from dams fed a high-energy diet. Significantly obese mice: mice with a highly elevated body fat $(>11 \%)$ derived from dams fed a high-energy diet. Values are means \pm S.E.M., ${ }^{*}$ - significant $(\mathrm{P}<0.05)$ compared different compared to controls (ovaries cultured without environmental contaminants).

Fig. 2a-c: Effect of Yucca shildegera extract $(10 \mu \mathrm{g} / \mathrm{mL})$ on ovarian progesterone (a), testosterone (b) and insulin-like growth factor I (IGF-I) (c) release in mice in different metabolic states. Values are means \pm S.E.M., * - significant $(\mathrm{P}<0.05)$ compared different compared to controls (ovaries cultured without yucca extract).

Normal-lean mice: mice with low-to-normal amounts of body fat (defined as body fat content $<8 \%$ ) derived from dams fed with a standard diet. Slightly obese mice: mice with a slightly elevated body fat $(8-11 \%)$ derived from dams fed a high-energy diet. Significantly obese mice: mice with a highly elevated body fat $(>11 \%)$ derived from dams fed a high-energy diet. 

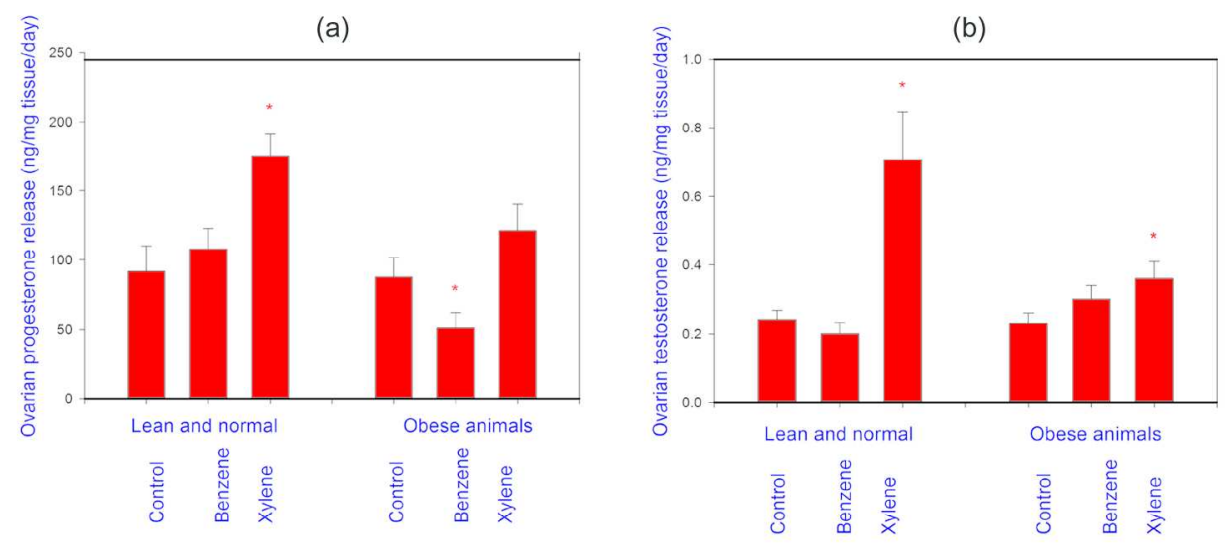

(c)

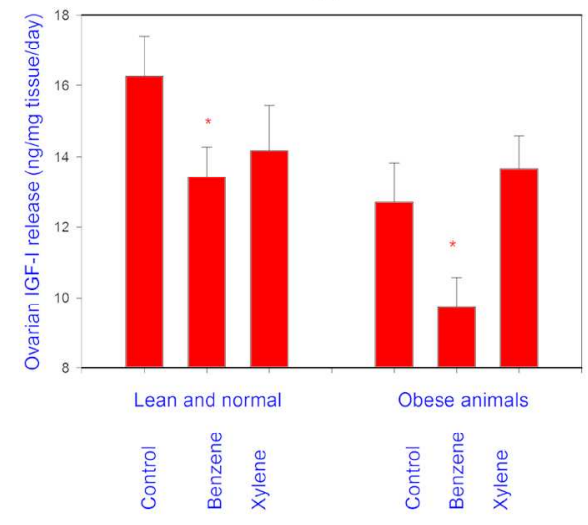

Fig. 1

$209 \times 186 \mathrm{~mm}(300 \times 300 \mathrm{DPI})$ 
(a)

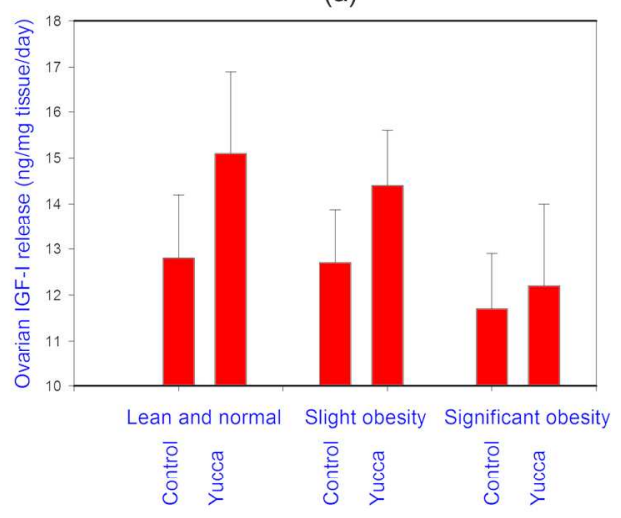

(c)

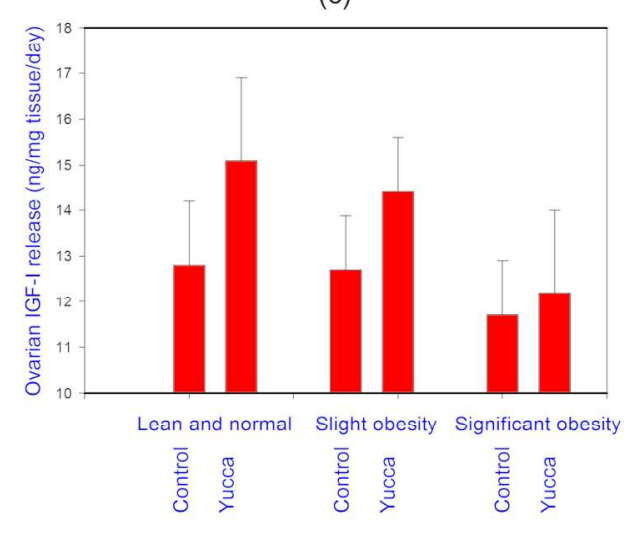

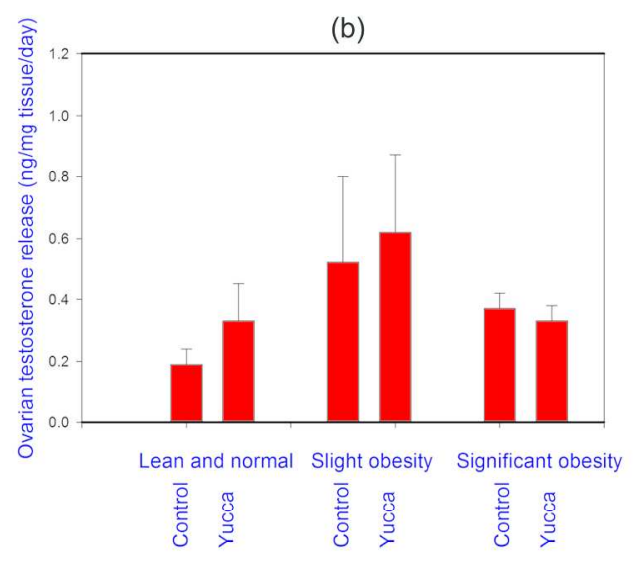

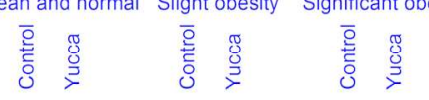

Fig. 2

$209 \times 184 \mathrm{~mm}(300 \times 300$ DPI $)$ 